\title{
EP300 wt Allele
}

National Cancer Institute

\section{Source}

National Cancer Institute. EP300 wt Allele. NCI Thesaurus. Code C52127.

Human EP300 wild-type allele is located in the vicinity of 22 q13.2 and is approximately 88 $\mathrm{kb}$ in length. This allele, which encodes the histone acetyltransferase p300 protein, is involved in both cyclic-AMP driven transcriptional activation and the cellular response to hypoxia. 